Brit. J. vener. Dis. (1959), 35, 149.

\title{
CLINICAL ASSESSMENT OF THE TREPONEMAL WASSERMANN REACTION*†
}

\author{
BY \\ ERIC M. C. DUNLOP AND I. N. ORPWOOD PRICE \\ The Whitechapel Clinic, The London Hospital
}

The value of a new serological test for syphilis is best assessed by examining its effects in two groups of patients; the first group should be composed of patients with no evidence of treponemal disease as determined by clinical examination and testing by already established serological methods, and the second should consist of patients known to have syphilis. Preliminary assessments of the treponemal Wassermann reaction (TWR) were reported by Price and Whelan (1957) and by Price (1958) and, as a result of this work, the present clinical study was planned.

\section{Material and Tests Employed}

The TWR was performed as a routine, together with the Wassermann reaction (WR) and Price's precipitation reaction (PPR), on all patients attending the Whitechapel Clinic of The London Hospital between November 1, 1957, and October 31, 1958.

The serological technique employed during the year under review for the WR has been described by Price (1950) and that for the PPR by Price (1948).

Over 10,000 TWRs were carried out on 4,105 patients (Table I), all of whose case records were reviewed. There were 3,078 men ( 778 coloured and 2,300 white) and 1,027 women (152 coloured and 875 white).

TABLE I

TOTAL PATIENTS REVIEWED BY RACE AND SEX

\begin{tabular}{c|c|c|c}
\hline \multirow{2}{*}{ Sex } & \multicolumn{2}{|c|}{ Race } & \multirow{2}{*}{ Total } \\
\cline { 2 - 3 } & Coloured & White & \\
\hline Women & 152 & 875 & 1,027 \\
\hline Men & 778 & 2,300 & 3,078 \\
\hline Total & 930 & 3,175 & 4,105 \\
\hline
\end{tabular}

\section{Controls}

Method of Study.-Requirements for the control group of patients without evidence of treponemal disease were as follows:

(1) No history suggesting treponemal disease.

* Read before the Medical Society for the Study of Venereal Diseases on April 24, 1959.

$\uparrow$ Received for publication August 10, 1959.
(2) No clinical sign suggesting treponemal disease.

(3) Negative initial standard serological tests for syphilis (STS).

(4) Negative confirmatory standard STS (carried out after an interval of not less than 6 weeks).

(5) No evidence of syphilis at the confirmatory clinical examination (carried out after an interval of not less than 6 weeks).

(6) No antibiotic with antitreponemal action given between the initial and the confirmatory examination and STS.

To fulfil these requirements, all suitable patients, in whom there was no evidence of treponemal infection either clinically or by standard serological tests, were asked to return for confirmatory examination and blood tests 6 weeks or more after the initial examination.

Results.-The 647 patients in this control group were subdivided into those who gave a history of having received a treponemicidal antibiotic or drug before the review (107) and those without such history (540).

(A) The main control group, consisting of patients with no previous history of having been given an antibiotic or drug, is considered first. The results of this analysis are shown in Table II (overleaf).

White Patients.-This group included 130 white women (15 per cent. of the white women who attended during the year). The initial TWR was positive in eight cases, and a treponemal immobilization test (TPI) was performed in seven of these with negative results.

There were 352 white men (15 per cent. of the white men who attended during the year). The initial TWR was positive in thirteen cases, and a TPI was performed in four of these with negative results. 
TABLE II

RESULTS IN 647 CONTROLS

\begin{tabular}{|c|c|c|c|c|c|c|c|c|c|c|}
\hline \multirow{2}{*}{$\begin{array}{r}\text { Controls } \\
\text { Race }\end{array}$} & \multirow[b]{2}{*}{ Sex } & \multicolumn{5}{|c|}{ (A) With No Previous History of Antibiotic } & \multirow{2}{*}{$\begin{array}{l}\text { (B) With } \\
\begin{array}{l}\text { Number } \\
\text { of Cases }\end{array}\end{array}$} & \multicolumn{2}{|c|}{$\begin{array}{c}\text { Previous History of } \\
\text { Antibiotic }\end{array}$} & \multirow{2}{*}{$\begin{array}{c}\text { Total } \\
\text { Controls }\end{array}$} \\
\hline & & $\begin{array}{l}\text { Number of } \\
\text { Cases }\end{array}$ & $\begin{array}{l}\text { Initial TWR } \\
\text { Positive }\end{array}$ & $\begin{array}{c}\text { TPI } \\
\text { Negative }\end{array}$ & $\begin{array}{c}\text { Initial TWR } \\
\text { Negative } \\
\text { Becoming } \\
\text { Positive }\end{array}$ & $\underset{\text { Negative }}{\text { TPI }}$ & & $\begin{array}{c}\text { Initial } \\
\text { TWR } \\
\text { Positive }\end{array}$ & $\begin{array}{c}\text { TPI } \\
\text { Negative }\end{array}$ & \\
\hline \multirow{3}{*}{ White } & Female & $\begin{array}{l}130 \\
\text { (15 per cent.) }\end{array}$ & 8 & 7 & 3 & 1 & 17 & 2 & 1 & 147 \\
\hline & Male & $\begin{array}{c}352 \\
\text { (15 per cent.) }\end{array}$ & 13 & 4 & 5 & 3 & 67 & 6 & 4 & 419 \\
\hline & Total & 482 & (4.4 per cent.) & 11 & 8 & 4 & 84 & 8 & 5 & 566 \\
\hline \multirow{3}{*}{ Coloured } & Female & $\begin{array}{c}11 \\
\text { (7 per cent.) }\end{array}$ & 4 & 4 & 3 & 1 & 1 & 1 & 1 & 12 \\
\hline & Male & $\begin{array}{c}47 \\
\text { ( } 6 \text { per cent.) }\end{array}$ & 20 & 11 & 6 & 4 & 22 & 9 & 2 & 69 \\
\hline & Total & 58 & $\begin{array}{c}24 \\
(41 \cdot 4 \text { per cent. })\end{array}$ & 15 & 9 & 5 & 23 & 10 & 3 & 81 \\
\hline Total .. & . & 540 & (8 $\cdot 3$ per cent. $)$ & 26 & 17 & 9 & 107 & $\begin{array}{c}18 \\
(16 \cdot 8 \text { per } \\
\text { cent. })\end{array}$ & 8 & 647 \\
\hline
\end{tabular}

Thus the initial TWR was positive in 21 cases ( 4.4 per cent.) of this group of white patients who had no evidence of syphilis either clinically or on testing by methods other than the TWR.

Coloured Patients.-There were only eleven coloured women who fulfilled the criteria for the control group and they comprised 7 per cent. of the coloured women who attended during the year. The initial TWR was positive in four cases, and the TPI was negative in all of them.

There were 47 coloured men ( 6 per cent. of those reviewed). The initial TWR was positive in twenty cases and the TPI was performed in eleven of them with negative results.

Thus, out of 58 coloured patients without evidence of treponemal disease, the initial TWR was positive in 24 (41 per cent.), and the TPI was performed in fifteen of these 24 cases with negative results.

Total.-Out of 540 patients in this main control group, who were selected as having no evidence of syphilis or yaws, no less than $45(8 \cdot 3$ per cent.) had an initially positive TWR.

As already noted, for a patient to be admitted to the control series, the initially negative standard STS, performed in parallel with the TWR, had to be repeated with negative result after an interval of not less than 6 weeks. Thus all the 540 control cases had one or more TWRs after the original test.

The sixth column of Table II shows that in seventeen cases out of $540(3 \cdot 2$ per cent.) the TWR, although initially negative, became positive. This occurred in patients under supervision in whom there was no evidence of syphilis. In nine of these seventeen the TPI was performed, with negative results. This finding is relevant at the present stage, but it also gives information on the reproducibility of the TWR. If these seventeen patients are considered together with the 45 in which the TWR was initially positive, then a total of $62(11.5$ per cent.) of the 540 control cases gave positive results to the TWR.

In the 58 coloured patients the TWR was positive initially in 24 and subsequently in a further nine, to make a total of 33 cases ( 57 per cent.) in which the test was positive. The countries of origin of these patients were as follows:

\begin{tabular}{|c|c|c|}
\hline Caribbean Zone & 27 & (TWR positive in 15 ) \\
\hline West Africa & 6 & (TWR positive in 4 ) \\
\hline India & 11 & (TWR positive in 4 ) \\
\hline Pakistan & 12 & (TWR positive in 10) \\
\hline Burma & 1) & (bo \\
\hline Arabia & & \\
\hline
\end{tabular}

(B) There is further evidence from the second control group, comprising patients who fulfilled all the criteria originally laid down, but who had received a treponemicidal drug or antibiotic before the review. Table II shows that, of 107 such cases, the initial TWR was positive in eighteen $(16 \cdot 8$ per cent.), and the TPI, performed in eight of these, was negative. 
Other "Controls".-Further evidence is given in Table III. In 25 patients the TWR was positive, although there was no evidence of treponemal disease and the standard STS were negative on two or more occasions. They cannot be included in the control group proper either because they received a treponemicidal antibiotic after the initial blood test, or because they were under observation for less than 6 weeks. In these 25 patients, although the TWR was positive, the subsequent TPI was negative.

TABLE III

OTHER "CONTROLS"

All were TWR Positive and TPI Negative with No History and No Signs, but they had received Antibiotic Treatment after the Initial TWR, or were observed for less than 6 weeks

\begin{tabular}{ll|lll|c|c|c}
\hline Sex &. & $\ldots$ & $\ldots$ &. & Male & Female & Total \\
\hline Race &.. & Coloured & $\ldots$ & 11 & 4 & 15 \\
\cline { 2 - 6 } & White &. & $\ldots$ & 5 & 5 & 10 \\
\hline Total & $\ldots$ & $\ldots$ & $\ldots$ & $\ldots$ & 16 & 9 & 25 \\
\hline
\end{tabular}

The control group has been comprised selectively of patients with no evidence of treponemal disease either clinically, or by serological tests other than the TWR. In the 4,105 patients reviewed, however, thirteen were discovered without definite history or signs of treponemal disease, in whom the standard STS were negative but the TWR and subsequent TPI proved positive. These patients are shown in Table IV. There is no doubt that if the positive TWR had not led to the performance of a TPI test, these cases would have been overlooked. It is interesting that twelve out of the thirteen patients were coloured persons.

TABLE IV

PATIENTS WITH POSITIVE TWR AND TPI ONLY (No History or Signs)

\begin{tabular}{|c|c|c|c|c|c|c|}
\hline Sex & . & . & $\cdots$ & Male & Female & Total \\
\hline \multirow{2}{*}{ Race } & \multirow{2}{*}{. } & Coloured & $\ldots$ & 7 & 5 & 12 \\
\hline & & White .. & . & Nil & 1 & 1 \\
\hline Total & . & $\ldots$ & $\ldots$ & 7 & 6 & $13^{*}$ \\
\hline
\end{tabular}

* TPI $=100$ per cent. in eight, "doubtful" in one, 58-82 per cent. in four.

Reproducibility.-A serological test for syphilis should be specific and sensitive, and the results it gives should be reproducible. Table $\mathrm{V}$ gives details of 22 cases in the control group in which the TWR, although initially negative, became positive.

Group A consisted of seventeen patients with no history of previous treatment with treponemicidal drug or antibiotic. In eight white patients the TWR was initially negative and became positive; in four of them a TPI was performed and was negative. In the smaller group of coloured control patients there were nine such cases and in five of them the TPI was performed and was negative.

Group B consisted of five patients with a history of previous treatment with treponemicidal drug or antibiotic. There were four white patients; the TPI was performed in two and was negative. There was one coloured patient.

These patients were under clinical observation and, although the TWR became positive, none developed evidence of syphilis.

TABLE V

REPRODUCIBILITY OF TWR IN CONTROLS

\begin{tabular}{l|c|c|c|c|c}
\hline \multicolumn{1}{c|}{ Controls } & \multicolumn{2}{c|}{$\begin{array}{c}\text { (A) No Previous } \\
\text { Antibiotic }\end{array}$} & \multicolumn{2}{c}{$\begin{array}{c}\text { (B) Previous } \\
\text { Antibiotic }\end{array}$} \\
\hline Race & Sex & $\begin{array}{c}\text { TWR Initially } \\
\text { Negative } \\
\text { Subsequently } \\
\text { Positive }\end{array}$ & $\begin{array}{c}\text { TPI } \\
\text { Nega- } \\
\text { tive }\end{array}$ & $\begin{array}{c}\text { TWR Initially } \\
\text { Negative } \\
\text { Subsequently } \\
\text { Positive }\end{array}$ & $\begin{array}{c}\text { TPI } \\
\text { Nega- } \\
\text { tive }\end{array}$ \\
\hline White & Female & 3 & 1 & 1 & - \\
\hline Male & Total & 5 & 3 & 3 & 2 \\
\hline Coloured & Female & 3 & 4 & 4 & 2 \\
\hline Total & Total & 6 & 1 & - & - \\
\hline & $\cdots$ & 9 & 5 & 1 & - \\
\hline
\end{tabular}

The TPI was negative in 35 members of the main control group in whom the TWR was positive in one or more tests. Reproducibility was studied in these cases by comparing the initial TWR with the subsequent TWR results (Table VI). In nineteen white patients, subsequent TWRs were "concordant" in fourteen and "discordant" in five. In sixteen coloured patients, subsequent TWRs were "concordant" in eleven and "discordant" in five. Thus,

TABLE VI

CONCORDANCE OF INITIAL TWR WITH SUBSEQUENT TWRS IN CONTROLS WITH NEGATIVE TPI

\begin{tabular}{c|c|c|c|c}
\hline \multirow{2}{*}{ Race } & Sex & "Concordant” & "Discordant" & Total \\
\hline \multirow{2}{*}{ White } & Female & 5 & 2 & 7 \\
\cline { 2 - 4 } & Male & 9 & 3 & 12 \\
\cline { 2 - 4 } & Total & 14 & 5 & 19 \\
\hline \multirow{2}{*}{ Coloured } & Female & 2 & 2 & 4 \\
\cline { 2 - 4 } & Male & 9 & 3 & 12 \\
\hline Total & Total & 11 & 5 & 16 \\
\hline & $\ldots$ & 25 & 10 & 35 \\
\hline
\end{tabular}


in these 35 patients, in all of whom the TPI was negative and none of whom had received a treponemicidal antibiotic or drug during the period of observation, the results of the TWR were "concordant" in 25 and "discordant" in ten.

Another way of assessing reproducibility is to analyse the results of the TWR in all cases in the main control group (Table VII). There were 342 white men in whom two or more tests (a total of 841 TWRs) gave concordant results; in ten cases the results were discordant. Similarly 125 white women had 268 concordant TWRs, and in five cases the results were discordant. Thus, in 467 white patients, 1,109 concordant TWRs were performed, and in fifteen cases ( 3 per cent.) the results were discordant. This may be compared with the total of 43 coloured patients in whom 110 TWRs gave concordant results, and the fifteen ( 26 per cent.) in whom the results were discordant.

TABLE VII

REPRODUCIBILITY IN CONTROLS

\begin{tabular}{l|c|c|c|c}
\hline \multirow{2}{*}{ Race } & \multirow{2}{*}{ Sex } & \multicolumn{2}{|c|}{ “Concordant" } & "Discordant" \\
\cline { 3 - 4 } & & Cases & Sera & Cases \\
\hline \multirow{3}{*}{ White } & Male & 342 & 841 & 10 \\
\cline { 2 - 3 } & Female & 125 & 268 & 5 \\
\hline & Total & 467 & 1,109 & $\begin{array}{c}15 \\
(3 \text { per cent. })\end{array}$ \\
\hline \multirow{3}{*}{ Coloured } & Male & 37 & 98 & 10 \\
\hline & Female & 6 & 12 & 5 \\
\hline Total & Total & 43 & 110 & $\begin{array}{c}15 \\
(26 \text { per cent. })\end{array}$ \\
\hline
\end{tabular}

It can be concluded that the reproducibility of the TWR is poor, especially in tests on sera from coloured patients.

\section{Syphilis Group}

Criteria for Selection.-All cases were studied in which a diagnosis of syphilis had been made at any time and in which the result of at least one TWR was available. From these a smaller group was selected which satisfied the strictest diagnostic criteria and, in this group, the results obtained with the TWR were compared with those obtained with the WR, PPR, and TPI.

Primary and Secondary Syphilis.-Only patients in whom treponemes had been found on darkfield examination were included.
Early Latent Syphilis.-This diagnosis was accepted only if one or more of the following criteria were satisfied:

(a) The patient was known to have had negative STS within the four years prior to diagnosis.

(b) The patient's consort had developed syphilis but was known to have had previous negative STS as above.

(c) The consort had darkfield positive lesions, or clinical secondary syphilis with positive STS.

(d) The patient had recently given birth to a child suffering from congenital syphilis.

Late Latent Syphilis.-If the historical evidence was sufficient this diagnosis was used, but the majority of cases of latent syphilis fell into the category of "latent syphilis of unknown duration".

"Syphilis or Yaws".-This category included coloured patients who had been born in areas where yaws occurs and were suffering from treponemal disease, other than early syphilis, congenital syphilis, or involvement of the neurological or cardiovascular systems.

Method of Study.-The results of the WR, PPR, and TWR at the time of diagnosis were recorded on an abstract sheet as "Positive", "Negative", or "No data", and the results of subsequent tests were entered in the same way under the appropriate time interval from the date of diagnosis. The TPI was similarly recorded with additional provision for the entering of "doubtful" results. Data so obtained were transferred to punched cards and mechanically sorted.

Results. -439 cases of syphilis proved suitable for this study and the results of the WR, PPR, and TWR in this group were analysed. It had been hoped that it would be possible to produce graphs to show the percentage of positive results for each test, at diagnosis, and at intervals after treatment. Owing to the small numbers in the different groups this has been possible in only some instances. Cases in which clinical or serological relapse occurred after treatment, or in which lesions of late syphilis developed, have been excluded, and the following charts show what happened after the successful treatment of syphilis. Follow-up tests were also excluded in those cases in which treatment had been inadequate.

In the construction of the charts which outline the results of individual tests before and after treatment in the different forms of syphilis, minor variations of 
technique in the earlier tests have been ignored. All the tests were performed at the Laboratory of the Whitechapel Clinic.

Sero-Negative Primary Syphilis.-Fig. 1 shows the results in 44 cases. At diagnosis all forty cases in which the WR had been performed, and all 29 in which the PPR was carried out, gave negative results. This is so by definition. One out of the fourteen cases in which the TWR was performed, however, gave a positive result, and this was in a coloured patient.

The next set of columns shows the results of tests on all sera examined within 3 months after diagnosis. Here five out of eleven TWR results were positive and all the WR, PPR, and TPI results were negative.

Table VIII summarizes all the follow-up tests; only two proved positive out of $335 \mathrm{WRs}$ and all the 299 PPRs were negative, but eight out of sixty TWRs were positive. This appears to be in keeping with the high percentage of positive TWRs in the control group.
TABLE VIII

SUMMARY OF FOLLOW-UP IN 44 CASES OF SERONEGATIVE PRIMARY SYPHILIS

\begin{tabular}{c|r|c|c}
\hline \multirow{2}{*}{ Test } & \multicolumn{2}{|c|}{ Result } & Total No. of \\
& Sera \\
\cline { 2 - 3 } & Negative & Positive & \\
\hline WR & 333 & 2 & 335 \\
PPR & 299 & 0 & 299 \\
TWI & 1 & 0 & 1 \\
TWR & 52 & 8 & 60 \\
\hline
\end{tabular}

In the seven coloured patients in this group the TWR at diagnosis was positive in one and negative in three. In follow-up tests the WR and PPR were negative in all 28 sera tested, the TWR being positive in one and negative in nine sera.

The number of coloured patients in the other diagnostic groups (except "Syphilis or Yaws") was small as in this first group, and no statistically valid difference between the white and coloured races was apparent in the results of serological tests. For this reason the two races are considered together in the following sections.

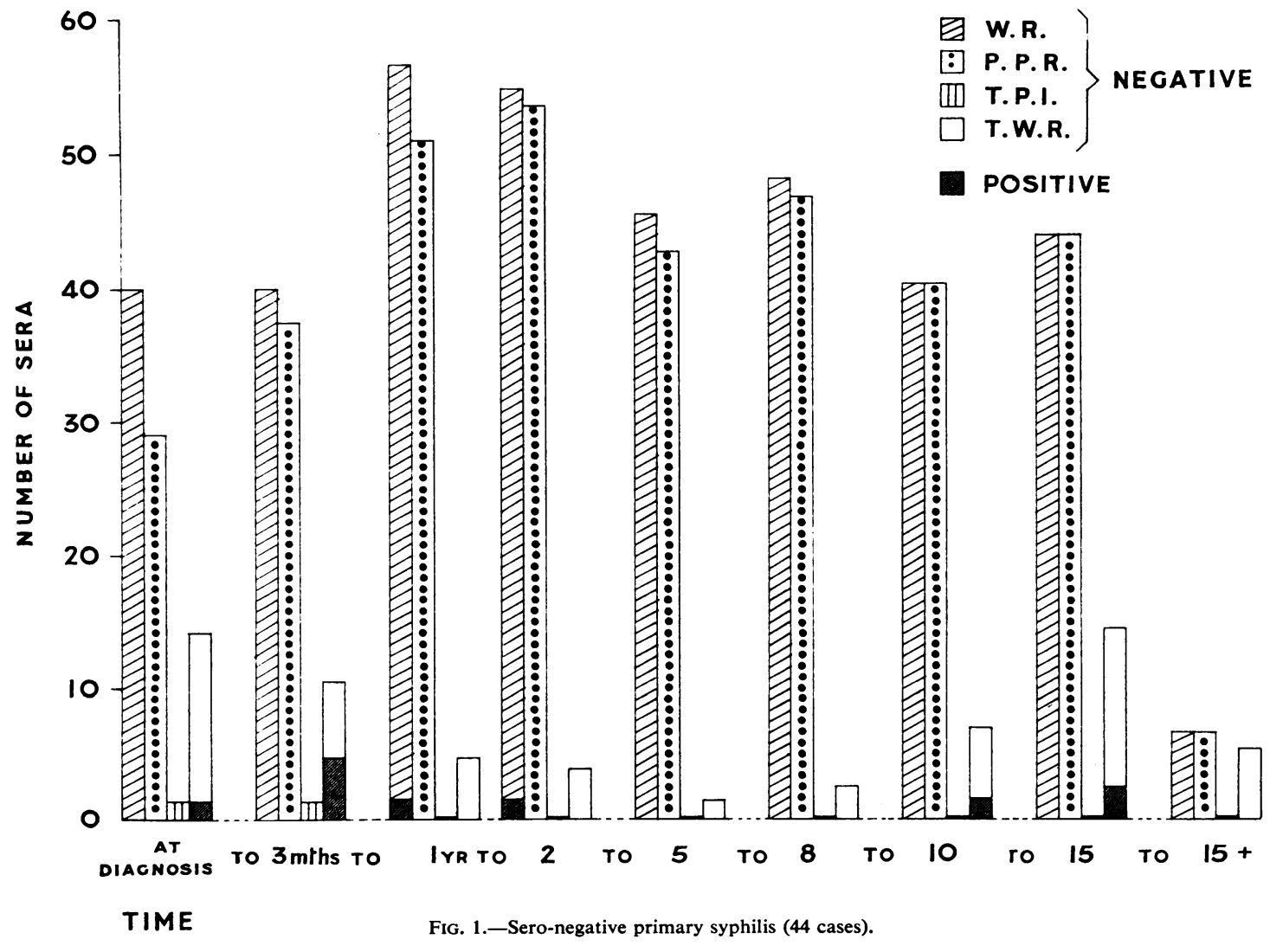


Sero-Positive Primary Syphilis.-There were 33 cases in this group (Fig. 2). At diagnosis the WR was positive in 31 of 32 cases, the PPR in 26 of 27, and the TWR in all eight cases tested.

In the follow-up tests (Table IX) the WR was negative in 211 sera and positive in fifty (19 per cent.), the PPR was negative in 229 and positive in nineteen ( 8 per cent.), the TPI was negative in four cases and the TWR was negative in 33 sera and positive in nineteen ( 36 per cent.), a higher level of positivity than was obtained with the other tests.

TABLE IX

SUMMARY OF FOLLOW-UP IN 33 CASES OF SERO-POSITIVE PRIMARY SYPHILIS

\begin{tabular}{|c|c|c|c|c|}
\hline \multirow{3}{*}{ Test } & \multicolumn{3}{|c|}{ Result } & \multirow{3}{*}{$\begin{array}{c}\text { Total } \\
\text { No. of Sera } \\
\text { Tested }\end{array}$} \\
\hline & \multirow{2}{*}{ Negative } & \multicolumn{2}{|c|}{ Positive } & \\
\hline & & No. & $\begin{array}{c}\text { Per } \\
\text { cent. }\end{array}$ & \\
\hline $\begin{array}{c}\text { WR } \\
\text { PPR } \\
\text { TPI } \\
\text { TWR }\end{array}$ & $\begin{array}{r}211 \\
229 \\
4 \\
33\end{array}$ & $\begin{array}{r}50 \\
19 \\
0 \\
19\end{array}$ & $\begin{array}{r}19 \\
8 \\
0 \\
36\end{array}$ & $\begin{array}{r}261 \\
248 \\
4 \\
52\end{array}$ \\
\hline
\end{tabular}

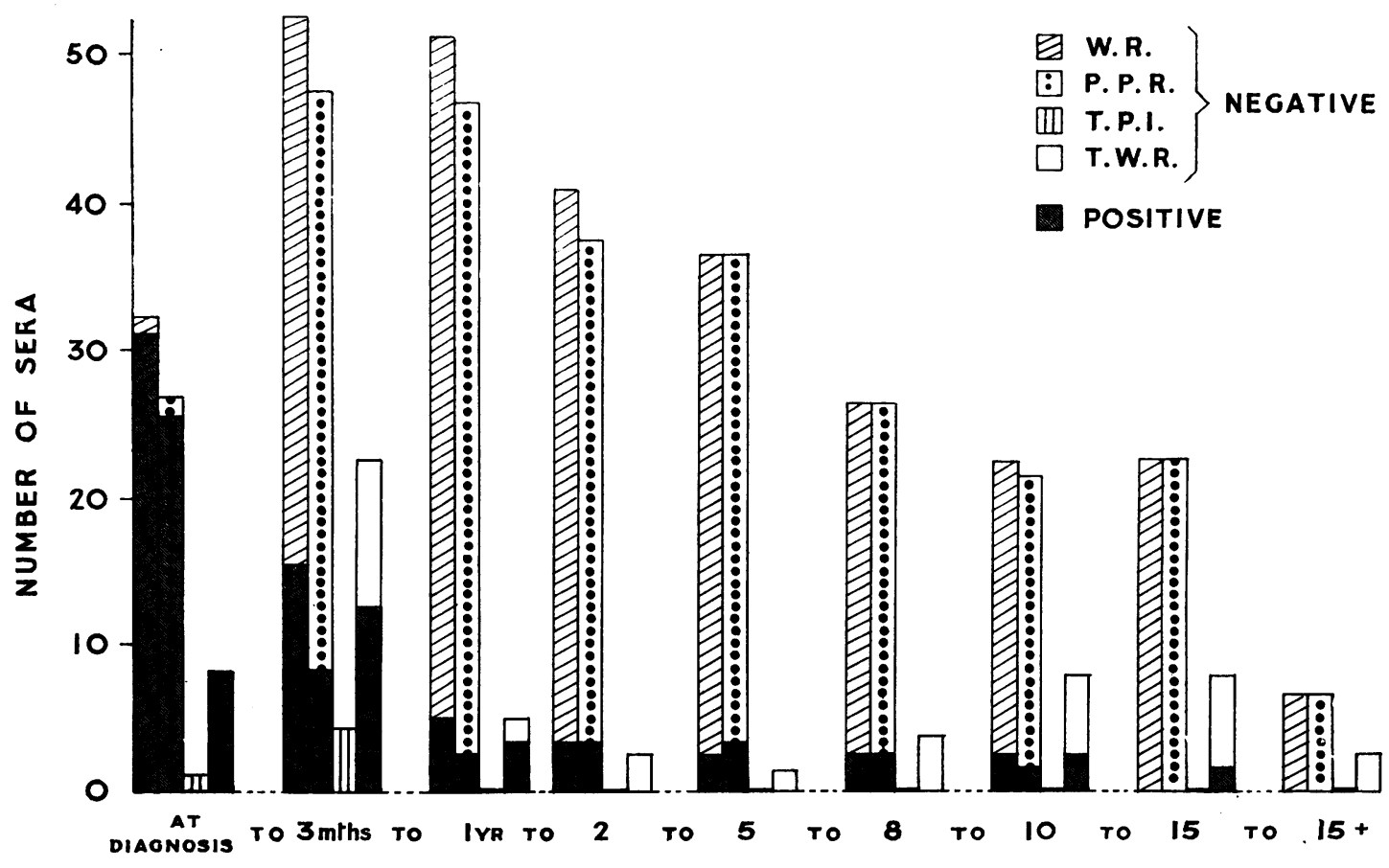

TIME

FIG. 2.-Sero-positive primary syphilis (33 cases). 
Secondary Syphilis.-There were forty cases in this group (Fig. 3). All tests gave positive results at diagnosis, and after treatment the WR and PPR showed a rapid reversal to negative. In the followup tests (Table $X$ ) the WR was negative in 272 sera and positive in 53 (16 per cent.), the PPR was negative in 243 and positive in 46 (16 per cent.), and the TWR was negative in thirty and positive in twenty (40 per cent.). Again there was a relatively large number of positive results with the TWR.
TABLE X

SUMMARY OF FOLLOW-UP IN 40 CASES OF SECONDARY SYPHILIS

\begin{tabular}{|c|c|c|c|c|}
\hline \multirow{3}{*}{ Test } & \multicolumn{3}{|c|}{ Result } & \multirow{3}{*}{$\begin{array}{c}\text { Total } \\
\text { No. of Sera } \\
\text { Tested }\end{array}$} \\
\hline & \multirow{2}{*}{ Negative } & \multicolumn{2}{|c|}{ Positive } & \\
\hline & & No. & $\begin{array}{c}\text { Per } \\
\text { cent. }\end{array}$ & \\
\hline $\begin{array}{c}\text { WR } \\
\text { PPR } \\
\text { TPI } \\
\text { TWR }\end{array}$ & $\begin{array}{r}272 \\
243 \\
\frac{1}{30}\end{array}$ & $\begin{array}{l}53 \\
46 \\
20\end{array}$ & $\begin{array}{l}\frac{16}{16} \\
\frac{40}{40}\end{array}$ & $\begin{array}{r}325 \\
289 \\
\overline{50}\end{array}$ \\
\hline
\end{tabular}

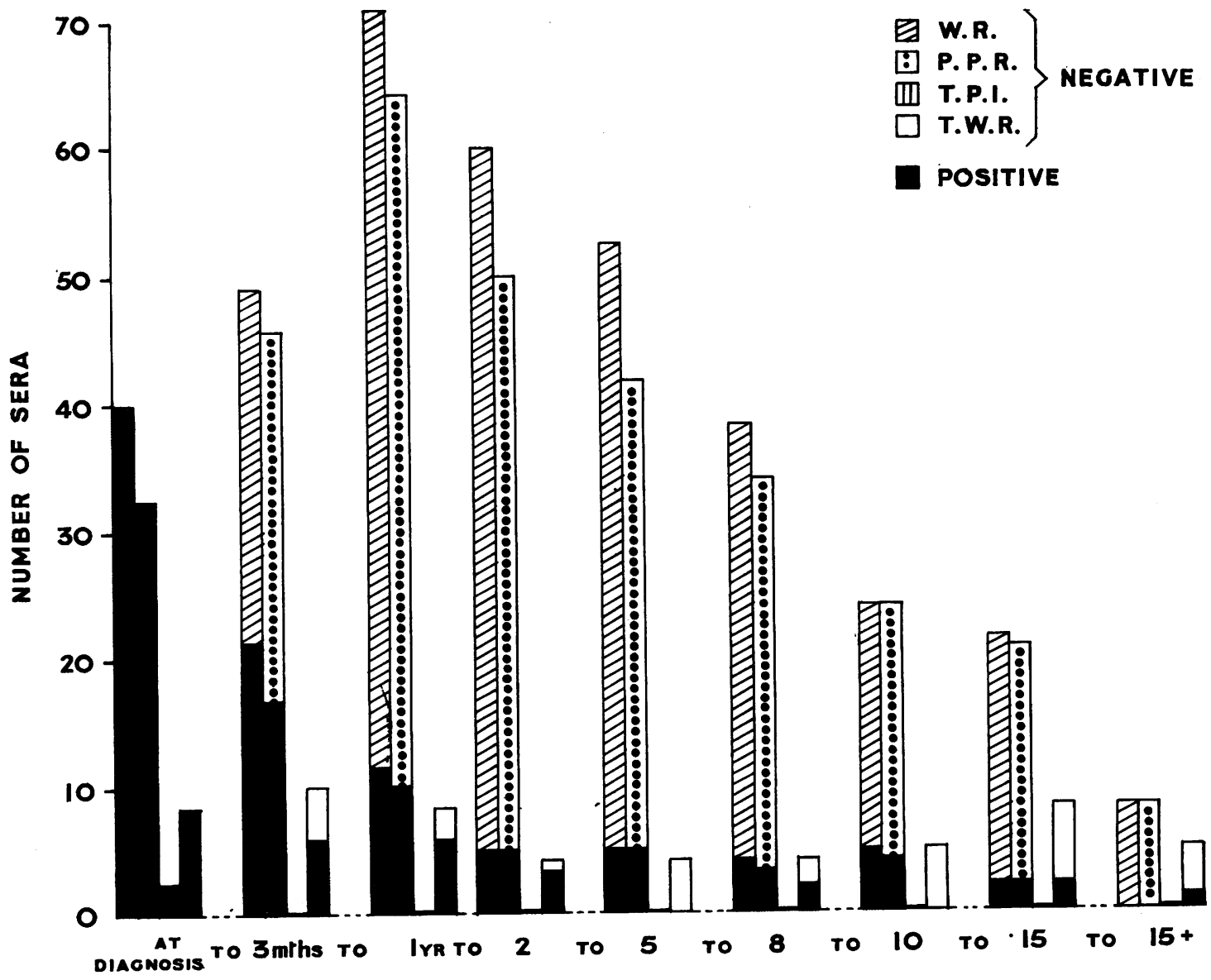

TIME

FIG. 3.-Secondary syphilis (40 cases). 


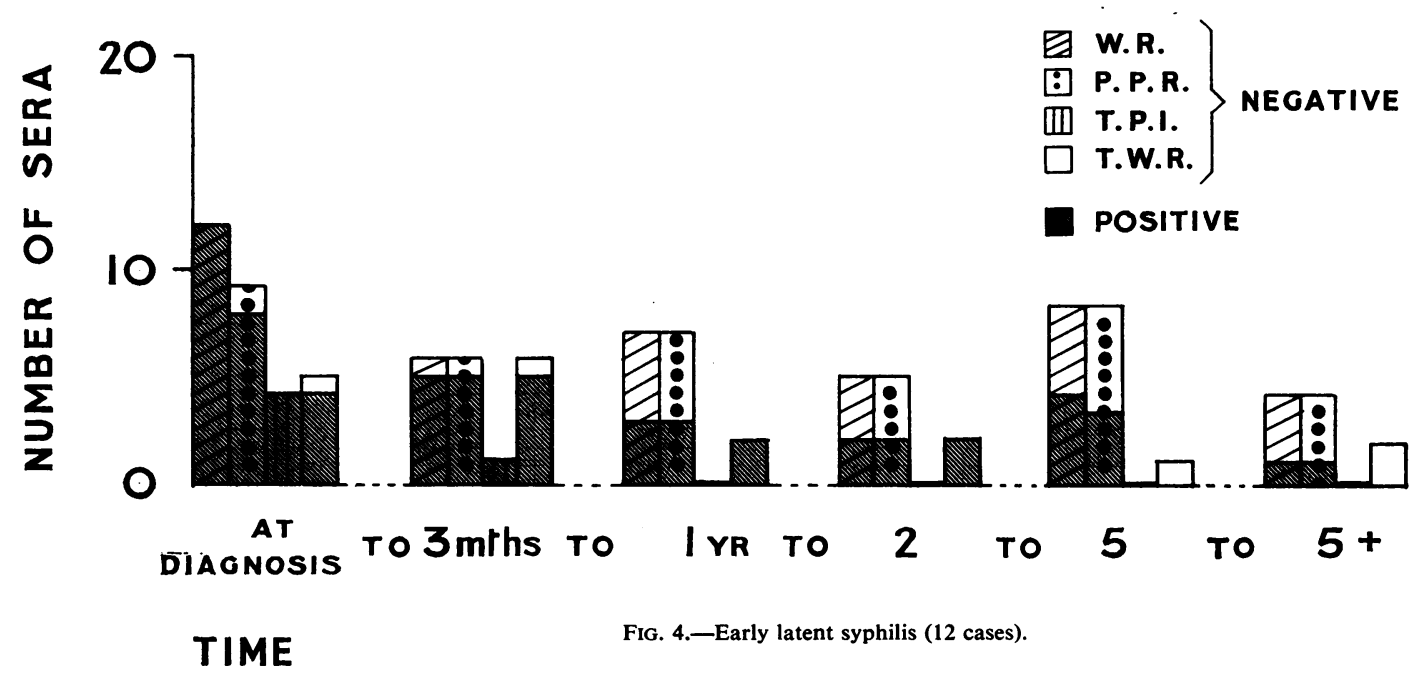

Early Latent Syphilis.-There were only twelve cases in this selected group (Fig. 4). At diagnosis the WR was positive in all twelve, the PPR in eight cases out of nine, the TPI in four out of four, and the TWR in four out of five. In the follow-up tests (Table XI), the WR was negative in fifteen sera and positive in fifteen ( 50 per cent.), the PPR was negative in sixteen and positive in fourteen ( 47 per cent.), and the TWR was negative in four and positive in seven.

TABLE XI

SUMMARY OF FOLLOW-UP IN 12 CASES OF EARLY LATENT SYPHILIS

\begin{tabular}{|c|c|c|c|c|}
\hline \multirow{3}{*}{ Test } & \multicolumn{3}{|c|}{ Result } & \multirow{3}{*}{$\begin{array}{c}\text { Total } \\
\text { No. of Sera } \\
\text { Tested }\end{array}$} \\
\hline & \multirow[b]{2}{*}{ Negative } & \multicolumn{2}{|c|}{ Positive } & \\
\hline & & No. & $\begin{array}{c}\text { Per } \\
\text { cent. }\end{array}$ & \\
\hline $\begin{array}{l}\text { WR } \\
\text { PPR } \\
\text { TPI } \\
\text { TWR }\end{array}$ & $\begin{array}{r}15 \\
16 \\
0 \\
4\end{array}$ & $\begin{array}{r}15 \\
14 \\
1 \\
7\end{array}$ & $\begin{array}{l}50 \\
47 \\
- \\
-\end{array}$ & $\begin{array}{r}30 \\
30 \\
1 \\
11\end{array}$ \\
\hline
\end{tabular}

Latent Syphilis of Unknown Duration.-There were 66 cases in this group (Fig. 5, opposite). At diagnosis the WR was positive in 61 of 62 cases, the PPR in 46 of 48, the TPI in all of twelve, and the TWR in ten of eleven. In the follow-up tests (Table XII), the WR was positive in 310 sera (73 per cent.) and negative in 112, the PPR was positive in 248 (65 per cent.) and negative in 134, the TPI was positive in eighteen cases (the result in a further one being reported as "doubtful"), and the TWR was positive in 48 sera (69 per cent.) and negative in 22.

TABLE XII

SUMMARY OF FOLLOW-UP IN 66 CASES OF LATENT SYPHILIS OF UNKNOWN DURATION

\begin{tabular}{|c|c|c|c|c|}
\hline \multirow{3}{*}{ Test } & \multicolumn{3}{|c|}{ Result } & \multirow{3}{*}{$\begin{array}{c}\text { Total } \\
\text { No. of Sera } \\
\text { Tested }\end{array}$} \\
\hline & \multirow[b]{2}{*}{ Negative } & \multicolumn{2}{|c|}{ Positive } & \\
\hline & & No. & $\begin{array}{c}\text { Per } \\
\text { cent. }\end{array}$ & \\
\hline $\begin{array}{c}\text { WR } \\
\text { PPR } \\
\text { TPI } \\
\text { TWR }\end{array}$ & $\begin{array}{r}112 \\
134 \\
0 \\
22\end{array}$ & $\begin{array}{c}310 \\
248 \\
18^{*} \\
48\end{array}$ & $\begin{array}{r}73 \\
65 \\
100 \\
69\end{array}$ & $\begin{array}{r}422 \\
382 \\
18 \\
70\end{array}$ \\
\hline
\end{tabular}

"Plus one "doubtful" 


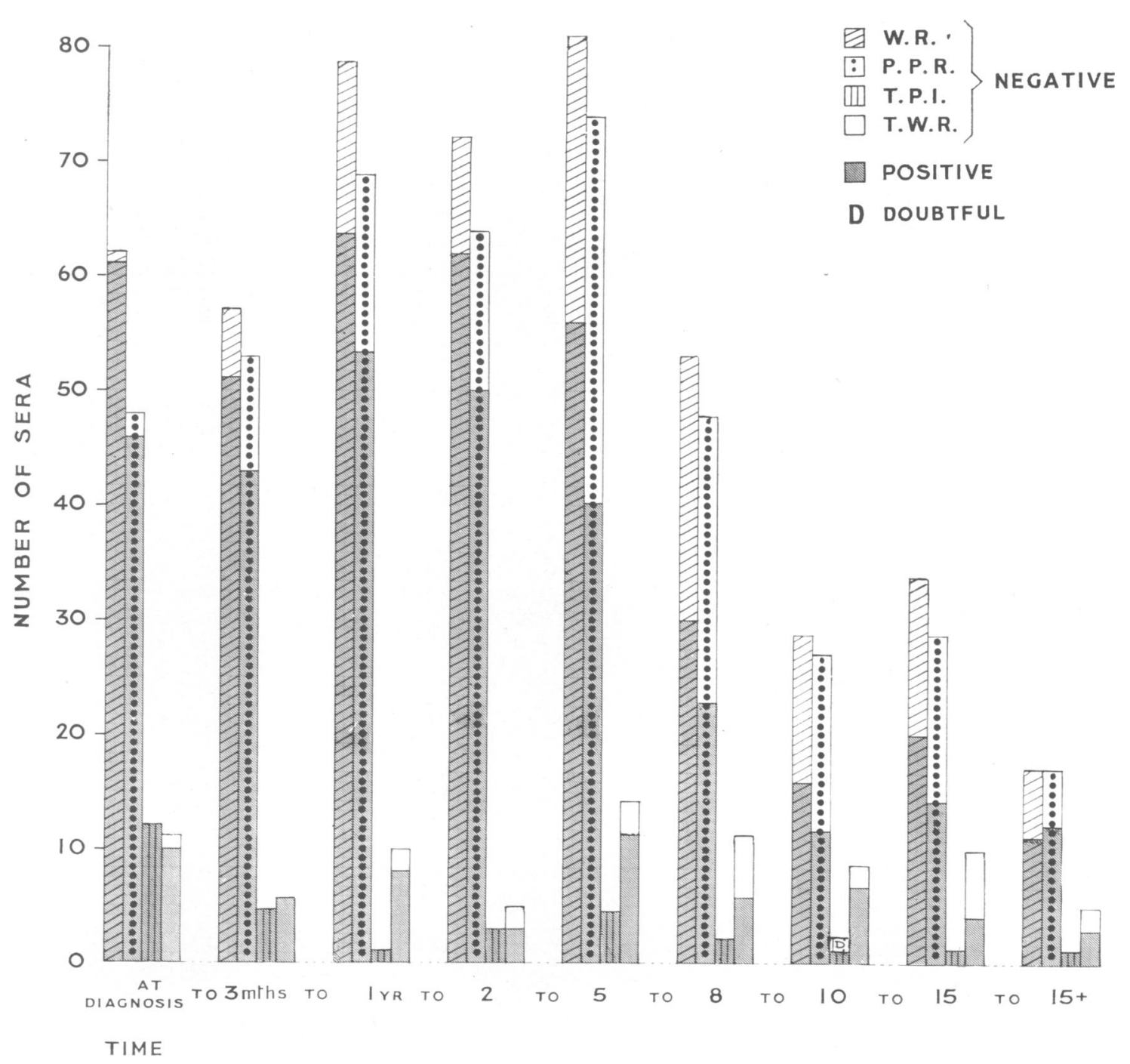

FIG. 5.-Latent syphilis of unknown duration (66 cases). 
Late Syphilis.-There were 96 cases in this group. In Fig. 6, the positive results are expressed as a percentage of tests performed.

At diagnosis the WR was positive in 85 out of 91 cases (93 per cent.), the PPR in 61 out of 69 (88 per cent.), the TWR in twenty out of 23 (87 per cent.), and the TPI in all of the nine cases tested.

In the follow-up tests (Table XIII), the WR was positive in 491 sera (71 per cent). and negative in 197, the PPR was positive in 440 (69 per cent.) and negative in 198, the TPI was positive in fifteen cases and negative in one (the result in a further one being reported as "doubtful"), and the TWR was positive in 61 sera (61 per cent.) and negative in 38 .

In view of the small number of sera tested by the TWR, the results of the various tests may be regarded as similar.

The increase in the percentage of positive tests fifteen years after diagnosis and subsequently may

TABLE XIII

SUMMARY OF FOLLOW-UP IN 96 CASES OF LATE SYPHILIS

\begin{tabular}{|c|c|c|c|c|}
\hline \multirow{3}{*}{ Test } & \multicolumn{3}{|c|}{ Result } & \multirow{3}{*}{$\begin{array}{c}\text { Total } \\
\text { No. of Sera } \\
\text { Tested }\end{array}$} \\
\hline & \multirow[b]{2}{*}{ Negative } & \multicolumn{2}{|c|}{ Positive } & \\
\hline & & No. & $\begin{array}{c}\text { Per } \\
\text { cent. }\end{array}$ & \\
\hline $\begin{array}{c}\text { WR } \\
\text { PPR } \\
\text { TPI } \\
\text { TWR }\end{array}$ & $\begin{array}{r}197 \\
198 \\
1 \\
38\end{array}$ & $\begin{array}{l}491 \\
440 \\
15^{*} \\
61\end{array}$ & $\begin{array}{l}71 \\
69 \\
94 \\
61\end{array}$ & $\begin{array}{r}688 \\
638 \\
16 \\
99\end{array}$ \\
\hline
\end{tabular}

* Plus one "doubtful"
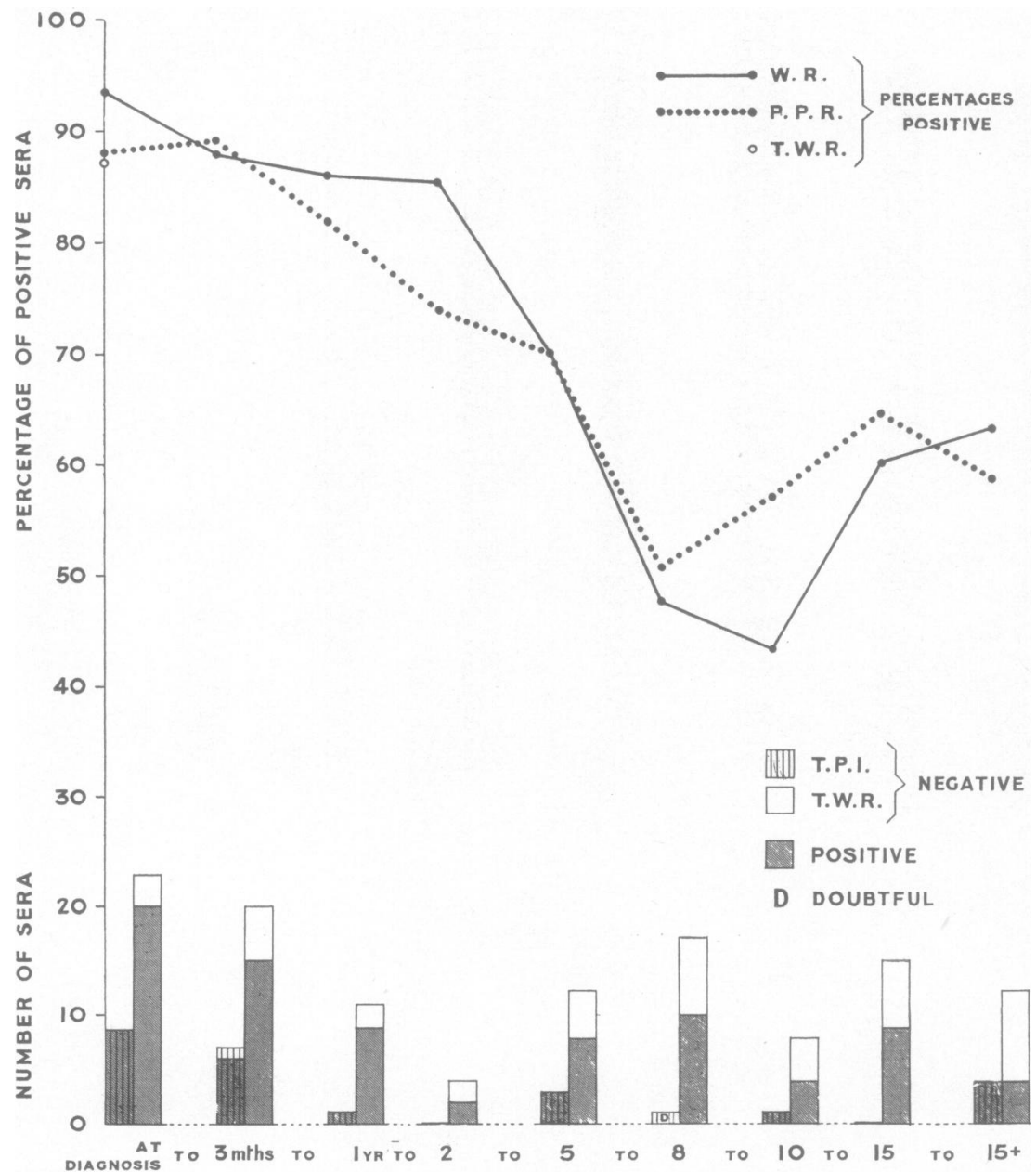
be due to the fact that more of the patients with positive STS tended to return for further observation.

Late Congenital Syphilis.-There were 45 cases in this group (Fig. 7). At diagnosis the WR was positive in all of 42 cases, the PPR in 22 out of 23 , and the TWR in six out of seven. Approximately 70 per cent. of sera tested between 10 and 15 years after diagnosis were positive.

In the total follow-up tests (Table XIV), the WR was positive in 266 sera ( 82 per cent.) and negative in 59, the PPR was positive in 258 (84 per cent.) and negative in fifty, the TPI was positive in nine cases and negative in two (the result in one further case being reported as "doubtful"), and the TWR was positive in 31 sera ( 74 per cent.) and negative in eleven.

TABLe XIV

SUMMARY OF FOLLOW-UP IN 45 CASES OF LATE CONGENITAL SYPHILIS

\begin{tabular}{|c|c|c|c|c|}
\hline \multirow{3}{*}{ Test } & \multicolumn{3}{|c|}{ Result } & \multirow{3}{*}{$\begin{array}{c}\text { Total } \\
\text { No. of Sera } \\
\text { Tested }\end{array}$} \\
\hline & \multirow[b]{2}{*}{ Negative } & \multicolumn{2}{|c|}{ Positive } & \\
\hline & & No. & $\begin{array}{c}\text { Per } \\
\text { cent. }\end{array}$ & \\
\hline $\begin{array}{l}\text { WR } \\
\text { PPR } \\
\text { TPI } \\
\text { TWR }\end{array}$ & $\begin{array}{r}59 \\
50 \\
2 \\
11\end{array}$ & $\begin{array}{c}266 \\
258 \\
9 * \\
31\end{array}$ & $\begin{array}{l}82 \\
84 \\
74\end{array}$ & $\begin{array}{r}325 \\
308 \\
11 \\
42\end{array}$ \\
\hline
\end{tabular}

* Plus one "doubtful"
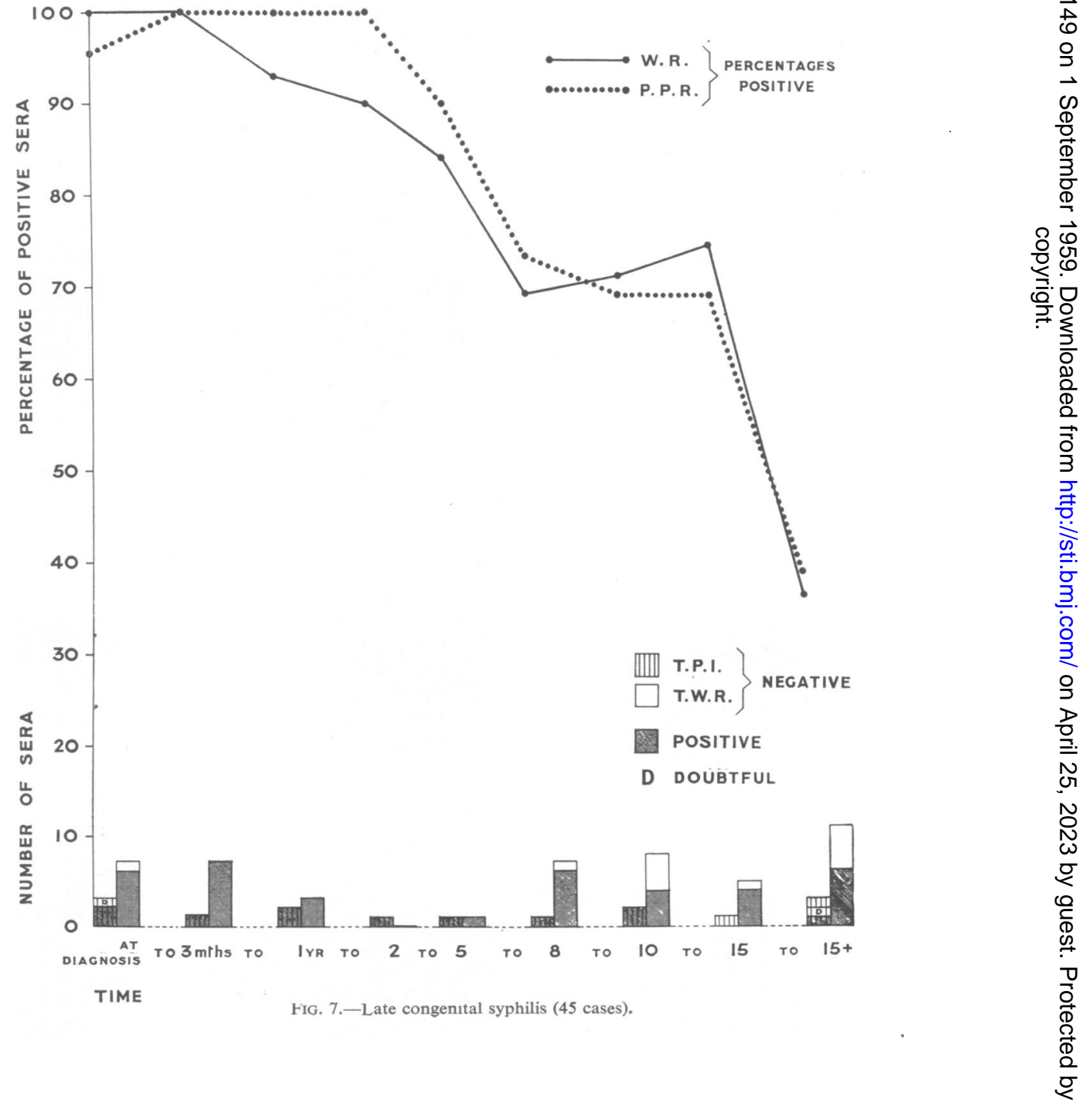
"Syphilis or Yaws".-There were 103 coloured patients in this group (Fig. 8). At diagnosis the TPI was positive in 64 cases and "doubtful" in two more, the TWR was positive in 77 out of 86 (90 per cent.), the WR in 77 out of 103 (75 per cent.), and the PPR in seventy out of one hundred. In tests carried out in the 3 months after diagnosis, the TPI was positive in all of thirteen cases, the TWR in 85 per cent. of sera tested, the WR in 79 per cent., and the PPR in 73 per cent. In the total follow-up tests (Table XV), the WR was positive in 118 sera ( 76 per cent.) and negative in 37, the PPR was positive in 103 (67 per cent.) and negative in 52, the TPI was positive in all of 20 cases, and the TWR was positive in 101 sera ( 83 per cent.) and negative in 21.
TABLE XV

SUMMARY OF FOLLOW-UP IN 103 CASES OF "SYPHILIS OR YAWS"

\begin{tabular}{c|c|c|c|c}
\hline & \multicolumn{2}{|c|}{ Result } & \multicolumn{1}{|c|}{$\begin{array}{c}\text { Total } \\
\text { Test }\end{array}$} \\
\cline { 2 - 3 } & & Positive & $\begin{array}{c}\text { Oof Sera } \\
\text { Tested }\end{array}$ \\
& Negative & No. & $\begin{array}{c}\text { Per } \\
\text { cent. }\end{array}$ & \\
\hline WR & 37 & 118 & 76 & 155 \\
PPR & 52 & 103 & 67 & 155 \\
TPI & 0 & 20 & 100 & 20 \\
TWR & 21 & 101 & 83 & 122 \\
\hline
\end{tabular}

In this group the TWR comes closer to the TPI in performance than do the standard STS. But this could be related to the fact that the TWR gave positive results in 41 per cent. of coloured controls.

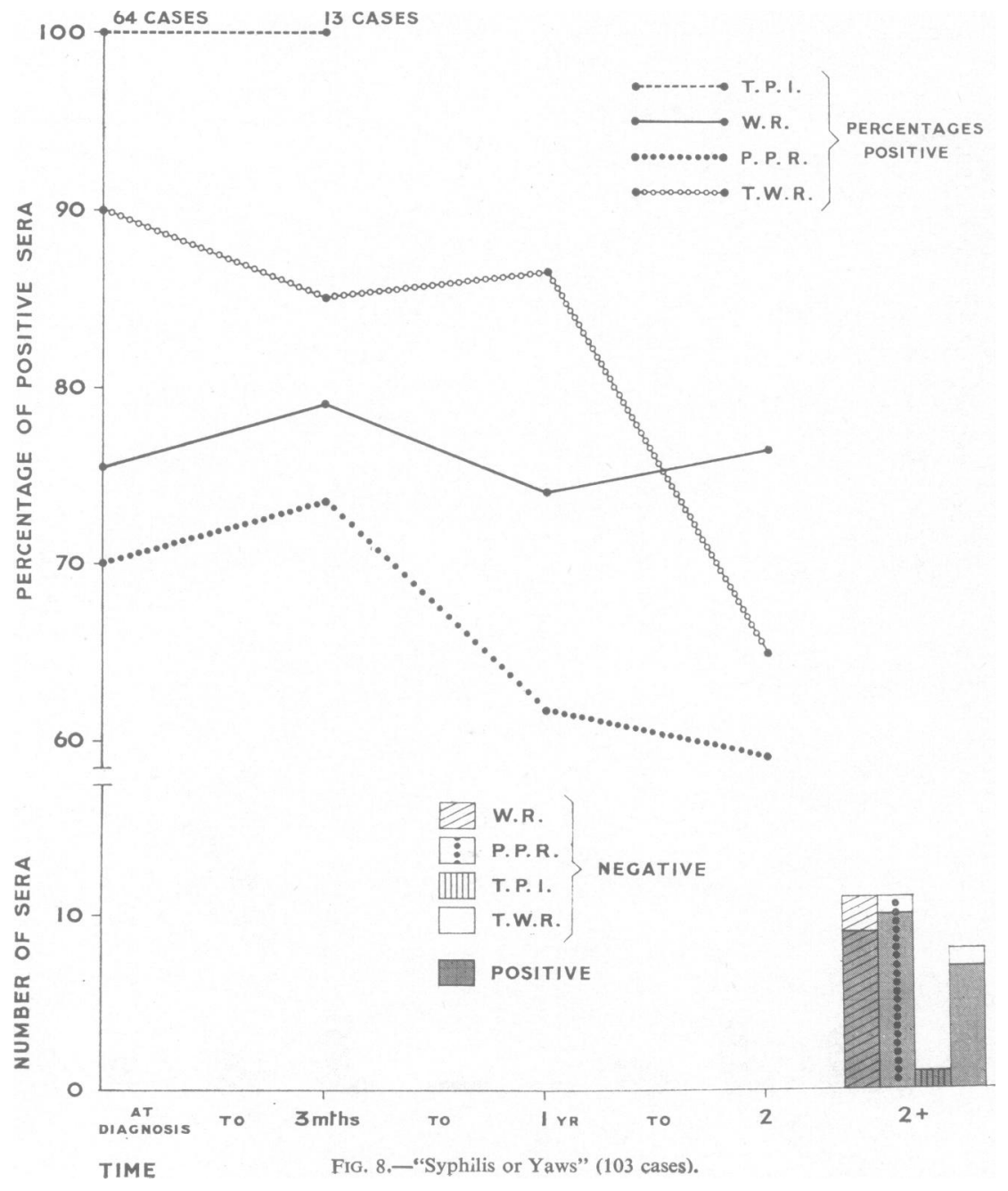


Non-Treponemal Reactors.-One or more TWRs were performed in 24 patients (nine white and fifteen coloured) diagnosed as non-treponemal reactors, in whom there was no clinical evidence of treponemal disease and the TPI was negative (Table XVIA and B). The TWR was positive in fifteen and negative in nine; the WR positive in thirteen and negative in eleven, and the PPR positive in only five and negative in nineteen.

TABLE XVIA

NON-TREPONEMAL REACTORS (TPI NEGATIVE)

\begin{tabular}{|c|c|c|c|c|c|c|}
\hline Sex & . & .. & . & Male & Female & Total \\
\hline \multirow{2}{*}{ Race } & & White & $\ldots$ & 4 & 5 & 9 \\
\hline & & Coloured & $\ldots$ & 4 & 11 & 15 \\
\hline Total & $\ldots$ & . & $\ldots$ & 8 & 16 & 24 \\
\hline
\end{tabular}

TABLE XVIB

RESULTS OF TESTS IN NON-TREPONEMAL REACTORS

\begin{tabular}{|c|c|c|c|c|c|}
\hline Tests & . & . & TWR & WR & PPR \\
\hline \multirow{4}{*}{ Results } & \multirow{2}{*}{$\begin{array}{l}\text { No. of } \\
\text { Cases }\end{array}$} & Positive .. & 15 & .13 & 5 \\
\hline & & Negative... & 9 & 11 & 19 \\
\hline & \multirow{2}{*}{$\begin{array}{l}\text { No. of } \\
\text { Sera }\end{array}$} & Positive .. & 39 & 40 & 7 \\
\hline & & Negative... & 30 & 29 & 62 \\
\hline
\end{tabular}

With regard to sera which were tested in parallel by the three methods, the TWR was positive in 39 sera and negative in thirty, the WR positive in forty and negative in 29 , and the PPR positive in only seven and negative in 62 .
In this group, therefore, results of the TWR did not approximate to those of the TPI.

\section{Summary}

(1) The results of standard serological tests for syphilis (STS) were compared with those of the TWR in 4,105 patients attending the Whitechapel Clinic of The London Hospital between November 1, 1957, and October 31, 1958.

(2) In a selected group of 482 white patients with no evidence of treponemal infection, the initial TWR gave positive results in 21 cases $(4 \cdot 4$ per cent.), whereas in a similar group of 58 coloured patients it was positive in 24 (41 per cent.).

(3) Reproducibility of the TWR was unsatisfactory.

(4) The results obtained in cases of syphilis which conformed to strict diagnostic criteria were analysed.

(5) In 24 non-treponemal reactors the TWR was positive in fifteen cases and negative in nine.

(6) There was considerable discrepancy between the results of the TWR and those of the WR, PPR, and TPI. This was apparently due to a high incidence of false positive reactions with the TWR.

(7) Because of the non-specificity and poor reproducibility of the TWR, this test in its present form cannot be regarded as a substitute for the TPI.

We thank our clinical colleagues and the office and laboratory staff whose cooperation has made this study possible. We are most grateful to Mr. J. Myson, A.M.R., and the staff of the Records Department, The London Hospital, for valuable help in the coding and analysis of data.

\section{REFERENCES}

Price, I. N. Orpwood (1948). J. clin. Path., 1, 91.

(1950). Brit. J. vener. Dis., 26, 172.

(1958). Ibid., 34, 91.

and Whelan, M. J. (1957). Ibid., 33. 1 